\title{
Fenton-Like Oxidation of Antibiotic Ornidazole Using Biochar-Supported Nanoscale Zero-Valent Iron as Heterogeneous Hydrogen Peroxide Activator
}

\author{
Yanchang Zhang ${ }^{1}$, Lin Zhao ${ }^{2, *}$, Yongkui Yang ${ }^{2}$ and Peizhe Sun ${ }^{2}$ \\ 1 School of Chemical Engineering and Technology, Tianjin University, Tianjin 300350, China; \\ zhangyanchang@tju.edu.cn \\ 2 School of Environmental Science and Engineering, Tianjin University, Tianjin 300350, China; \\ ykyang@tju.edu.cn (Y.Y.); sunpeizhe@tju.edu.cn (P.S.) \\ * Correspondence: zhaolin@tju.edu.cn
}

Received: 17 November 2019; Accepted: 23 December 2019; Published: 19 February 2020

\begin{abstract}
Biochar (BC)-supported nanoscale zero-valent iron (nZVI-BC) was investigated as a heterogeneous Fenton-like activator to degrade the antibiotic ornidazole (ONZ). The characterization of $\mathrm{nZVI-BC}$ indicated that $\mathrm{BC}$ could enhance the adsorption of $\mathrm{ONZ}$ and reduce the aggregation of nZVI. Thus, nZVI-BC had a higher removal efficiency (80.1\%) than nZVI and BC. The effects of parameters such as the $\mathrm{nZVI} / \mathrm{BC}$ mass ratio, $\mathrm{pH}, \mathrm{H}_{2} \mathrm{O}_{2}$ concentration, nZVI-BC dose, and temperature were systematically investigated, and the removal of ONZ followed a pseudo-second-order kinetic model. Finally, possible pathways of ONZ in the oxidation process were proposed. The removal mechanism included the adsorption of ONZ onto the surface of nZVI-BC, the generation of $\bullet \mathrm{OH}$ by the reaction of nZVI with $\mathrm{H}_{2} \mathrm{O}_{2}$, and the oxidation of ONZ. Recycling experiments indicated that the nZVI-BC/ $\mathrm{H}_{2} \mathrm{O}_{2}$ system is a promising alternative for the treatment of wastewater containing ONZ.
\end{abstract}

Keywords: nanoparticles; biochar; wastewater treatment; ornidazole

\section{Introduction}

Ornidazole (ONZ), which is a third-generation 5-nitroimidazole antibiotic, is widely used to treat infections owing to its excellent activity against anaerobic bacteria [1,2]. Compared with other antibiotics, ONZ has a longer elimination half-life and greater capacity to penetrate into lipidic tissues, which makes it a good choice in dental and gastrointestinal surgery [3]. However, it poses a risk to humans and wildlife if it is discharged into the environment owing to its potential genotoxic, carcinogenic, and mutagenic properties $[4,5]$. The presence of ONZ in the environment, such as surface water and ground water, was investigated [6]. Wastewater containing ONZ must be treated before entering the environment. However, the high aqueous solubility $(4.33 \mathrm{~g} / \mathrm{L})$ and low biodegradability of ONZ make it challenging to remove ONZ via traditional treatment techniques. A few studies were performed to eliminate ONZ using photocatalysts $[7,8]$. However, the complex procedures of these methods may limit their large-scale application, and it is desirable to develop more low-cost and efficient technologies to remove ONZ from wastewater.

Advanced oxidation processes (AOPs) are widely employed for the treatment of organic contaminants. Among the AOPs, the Fenton reaction is one of the most popular and effective methods for dealing with many pollutants $[9,10]$. The conventional Fenton reaction involves ferrous salts reacting with hydrogen peroxide under acidic conditions, generating hydroxyl radicals $(\bullet \mathrm{OH}$, oxidation potential of $2.8 \mathrm{eV}$ ) which can oxidize a wide range of contaminants rapidly. However, $\mathrm{Fe}^{3+}$ is easily precipitated as $\mathrm{Fe}(\mathrm{OH})_{3}$ sludge, which causes secondary pollution and reduces the 
degradation efficiency [11]. Nanoscale zero-valent iron (nZVI) was proposed as an alternative iron source to activate $\mathrm{H}_{2} \mathrm{O}_{2}$. nZVI can supply $\mathrm{Fe}^{2+}$ continuously and produce less sludge owing to ferric ion recycling in the system [12].

$$
\begin{gathered}
\mathrm{Fe}^{2+}+\mathrm{H}_{2} \mathrm{O}_{2} \rightarrow \mathrm{Fe}^{3+}+\bullet \mathrm{OH}+\mathrm{OH}^{-} . \\
2 \mathrm{Fe}^{3+}+\mathrm{Fe} \rightarrow 3 \mathrm{Fe}^{2+} .
\end{gathered}
$$

The heterogeneous Fenton process using nZVI was employed for the degradation of organic contaminants, particularly in the treatment of personal care products [13,14]. However, nZVI was easily oxidized in the presence of oxygen and tended to aggregate because of high surface energy [15], which had detrimental effects on the stability and catalytic activity. To overcome these drawbacks, porous materials such as zeolites [16], mesoporous carbon [17], montmorillonite [18], and mesoporous silica [19] were used as the supporting materials for nZVI immobilization, which reduced the aggregation and enhanced its transport.

Biochar (BC) is a carbon-rich material with a large surface area and a porous structure, and it is produced by the thermal conversion of biomass under oxygen-limited conditions. Recently, the application of $\mathrm{BC}$ in water treatment attracted considerable attention because $\mathrm{BC}$ is low-cost and abundant, and it has extraordinary adsorption properties for removing organic contaminants [20]. Several studies reported that BC with a large surface area can serve as an effective supporter of nZVI [21,22]. A biochar-supported nanoscale zero-valent iron composite was successfully used as a persulfate activator for removing nonylphenol and trichloroethylene [22,23]. In the present study, we attempted to degrade ONZ and analyze the related mechanism using an nZVI-BC/ $\mathrm{H}_{2} \mathrm{O}_{2}$ system owing to its strong oxidative capacity. So far, there are no reports on this. Therefore, the application of the nZVI-BC/ $\mathrm{H}_{2} \mathrm{O}_{2}$ system for the removal of ONZ is of great importance.

The objectives of this study were as follows: (1) to synthesize and characterize the nZVI-BC composites, (2) to investigate the effects of the initial $\mathrm{pH}, \mathrm{H}_{2} \mathrm{O}_{2}$ concentration, nZVI-BC dose, and temperature on the degradation of ONZ, (3) to assess the reusability and stability of nZVI-BC, and (4) to clarify the removal mechanism and possible pathways of ONZ in the nZVI-BC/ $\mathrm{H}_{2} \mathrm{O}_{2}$ system.

\section{Experimental Methods}

\subsection{Chemicals}

ONZ (>98\%), sodium borohydride $\left(\mathrm{NaBH}_{4},>98 \%\right)$, ferrous sulfate heptahydrate $\left(\mathrm{FeSO}_{4} \cdot 7 \mathrm{H}_{2} \mathrm{O}\right.$, $>99 \%$ ), hydrogen peroxide $\left(\mathrm{H}_{2} \mathrm{O}_{2}, 30 \%\right.$ aqueous solution), tert-butyl alcohol (TBA, $\left.>99.5 \%\right)$, and absolute ethyl alcohol were purchased from Aladdin, Shanghai. All the chemicals were analytical-grade, and ultra-pure water $(18.2 \mathrm{M} \Omega)$ was used in this study.

\subsection{Preparation of $n Z V I-B C$}

$\mathrm{BC}$ was produced via pyrolysis of bamboo sawdust. The bamboo sawdust was collected from a farm in Gongyi (Henan Province, China), washed several times, and dried at $80{ }^{\circ} \mathrm{C}$ overnight. The raw material was crushed and passed through a 40-mesh sieve. Then, it was placed into tightly filled ceramic crucibles and pyrolyzed in a muffle furnace at $600{ }^{\circ} \mathrm{C}$ under an oxygen-limited environment for $2 \mathrm{~h}$. The obtained $\mathrm{BC}$ was treated with $1 \mathrm{M} \mathrm{HCl}$ for $2 \mathrm{~h}$ to remove inorganic components and washed with distilled water several times to remove any residual acids.

The nZVI-BC was synthesized via a conventional liquid-phase reduction method. In brief, $4.96 \mathrm{~g}$ of $\mathrm{FeSO}_{4} \cdot 7 \mathrm{H}_{2} \mathrm{O}$ and $\mathrm{BC}(0.5,1.0,2.0,3.0 \mathrm{~g})$ were added to $100 \mathrm{~mL}$ of a water-ethanol solution $(w / w=3: 2)$ with stirring for $60 \mathrm{~min}$. Then, $100 \mathrm{~mL}$ of a $0.36 \mathrm{M} \mathrm{NaBH}_{4}$ solution was added to this mixture dropwise under vigorous mechanical agitation. Subsequently, the mixture was stirred for $1 \mathrm{~h}$. The black precipitant was collected via vacuum filtration and quickly washed with absolute ethyl alcohol and water three times each. Then, it was dried under vacuum conditions overnight and stored in an $\mathrm{N}_{2}$ 
atmosphere for further use. The four types of nZVI-BC composites with $\mathrm{Fe}^{0} / \mathrm{BC}$ mass ratios of 2:1, 1:1, 1:2, and 1:3 were denoted as nZVI-BC $1, \mathrm{nZVI}^{-B C_{2}}, \mathrm{nZVI-BC}{ }_{3}$, and $\mathrm{nZVI-BC}$, respectively. nZVI was prepared via the same method without the addition of $\mathrm{BC}$. The process can be described by the following reaction $[13,24]$ :

$$
\mathrm{Fe}^{2+}+2 \mathrm{BH}_{4}^{-}+6 \mathrm{H}_{2} \mathrm{O} \rightarrow \mathrm{Fe}+2 \mathrm{~B}(\mathrm{OH})_{3}+7 \mathrm{H}_{2} \uparrow .
$$

\subsection{Characterization}

The morphological characteristics were analyzed using scanning electron microscopy (SEM, S-4800, Hitachi Company, Japan) and transmission electron microscopy (TEM, JEM-1200EX, JEOL Ltd., Japan). The surface structure and composition were examined via X-ray diffraction (XRD) analysis using a Bruker D8 Advanced diffractometer with $\mathrm{Cu} / \mathrm{K} \alpha$ radiation $(\lambda=1.5406 \AA)$, as well as X-ray photoelectron spectroscopy (XPS, ESCALAB 250Xi, Thermo Corporation, USA). The specific surface area and the pore structure were determined using a Brunauer-Emmett-Teller (BET) analyzer (ASAP 2460, Micromeritics, USA). The Fourier-transform infrared (FTIR) spectra were acquired using a Nicolet 380 spectrometer. The zeta potentials were measured using a Zetasizer Nano ZS 90 (Malvern, UK).

\subsection{Batch Experiments}

All batch experiments were performed in 500-mL conical flasks sealed with rubber plugs in a water bath at a speed of $400 \mathrm{rpm}$. To initiate the experiments, different amounts of $\mathrm{H}_{2} \mathrm{O}_{2}$ and nZVI-BC were added to $300 \mathrm{~mL}$ of a $100 \mathrm{mg} / \mathrm{L} \mathrm{ONZ}$ solution. The effects of the initial solution $\mathrm{pH}(2.0-6.0)$, initial $\mathrm{H}_{2} \mathrm{O}_{2}$ concentration ( $\left.4-24 \mathrm{mM}\right)$, nZVI-BC dose $(0.05-0.40 \mathrm{~g} / \mathrm{L})$, and temperature $\left(15-45^{\circ} \mathrm{C}\right)$ were investigated by changing one factor while keeping the others constant. The $\mathrm{pH}$ of the ONZ solution was adjusted using $0.1 \mathrm{M} \mathrm{H}_{2} \mathrm{SO}_{4}$ or $\mathrm{NaOH}$. At regular intervals, an aliquot amount $(3 \mathrm{~mL})$ of the reaction solution was withdrawn, filtered through a $0.22-\mu \mathrm{m}$ membrane film, and quenched with TBA immediately for further analysis. All batch experiments were performed in triplicate to ensure reproducibility, and the relative errors were controlled within $\pm 5 \%$. The removal efficiency of ONZ was calculated as follows:

$$
\mathrm{R}(\%)=\frac{\mathrm{C}_{0}-\mathrm{C}_{\mathrm{t}}}{\mathrm{C}_{0}} \times 100,
$$

where $C_{0}$ and $C_{t}(m g / L)$ represent the ONZ concentrations at the initial time and time $t$, and $R(\%)$ represents the ONZ degradation efficiency.

\subsection{Analytical Methods}

The concentration of ONZ was measured in a Waters e2695 HPLC system equipped with an Agilent C18 column $(4.6 \times 250 \mathrm{~mm}, 5 \mu \mathrm{m})$. The mobile phase was composed of methanol and water $(20: 80, v / v)$ with a flow rate of $1.0 \mathrm{~mL} / \mathrm{min}$. The ONZ was measured at a wavelength of $318 \mathrm{~nm}$, and the column temperature was $30^{\circ} \mathrm{C}$. An ultraviolet-visible light (UV-Vis) spectrophotometer (D6000, Hach, USA) was used to obtain the UV spectra of the ONZ solution. The chemical oxygen demand (COD) and total organic carbon (TOC) were measured using a COD tester (DRB200, Hach, USA) and a TOC analyzer (TOC-VCPH, Shimadzu Corporation, Japan), respectively. The $\mathrm{pH}$ of the solution was measured using a Mettler-Toledo pH meter. An ion chromatograph (DX600, Dionex, USA) was used to detect the inorganic ions. The carbon content was determined by element analysis (Vario EL III, Elementar, Germany). The iron content was determined with inductively coupled plasma atomic emission spectrometry (ICP-OES, ICPOES730, Agilent, USA) after $\mathrm{HNO}_{3}$ digestion. 


\section{Results and Discussion}

\subsection{Characterization of $n Z V I-B C$}

The BET specific surface area and pore volume of the BC and the different nZVI-BC composites are presented in Table 1 . The specific surface area and pore volume of the nZVI-BC were significantly increased compared with those of the nZVI. The fraction of nZVI loaded on BC decreased from 50.8\% to $21.6 \%$ when the $\mathrm{Fe}^{0} / \mathrm{BC}$ mass ratio increased from 2:1 to 1:3 (Table S1, Supplementary Materials). The specific surface area of the nZVI-BC increased with an increase in the BC proportion. This may be because the $\mathrm{BC}$ provided enough sites for iron particles, and higher $\mathrm{BC}$ content favored the dispersion of nZVI. However, a further increase of BC content resulted in a lower BET surface area value due to the increasing aggregation of BC sheets $[25,26]$.

Table 1. Characteristics of nanoscale zero-valent iron (nZVI), biochar (BC) and different nZVI-BC composites.

\begin{tabular}{|c|c|c|}
\hline Name & $\begin{array}{l}\text { Specific Surface Area } \\
\qquad\left(\mathrm{m}^{2} / \mathrm{g}\right)\end{array}$ & $\begin{array}{l}\text { Pore Volume } \\
\qquad\left(\mathrm{cm}^{3} / \mathrm{g}\right)\end{array}$ \\
\hline nZVI & 12.56 & 0.0024 \\
\hline BC & 227.45 & 0.1745 \\
\hline $\mathrm{nZVI}-\mathrm{BC}_{1}(2: 1)$ & 62.03 & 0.1003 \\
\hline $\mathrm{nZVI}-\mathrm{BC}_{2}(1: 1)$ & 73.12 & 0.1205 \\
\hline$n Z V I-B C_{3}(1: 2)$ & 89.93 & 0.1278 \\
\hline $\mathrm{nZVI}-\mathrm{BC}_{4}(1: 3)$ & 86.39 & 0.1305 \\
\hline
\end{tabular}

The SEM images revealed that the BC had a microporous structure (Figure 1a), which was conducive to the impregnation of nZVI. The nZVI particles aggregated as clusters owing to the van der Waals forces (Figure 1b) [27]. In contrast, numerous small globular particles were distributed well on the BC surface (Figure 1c), indicating that iron nanoparticles successfully attached onto the BC without significant aggregation. The particles lost their spherical shape after the reaction (Figure 1d), suggesting the corrosion of $\mathrm{Fe}^{0}$ and the formation of iron-oxide products on the BC. Additionally, a TEM image indicated that the particles were attached uniformly onto the surface of $\mathrm{BC}$, and that the size of $\mathrm{nZVI}-\mathrm{BC}_{3}$ was approximately 20-50 nm (Figure 1f), which was in the nanoscale range. However, the nZVI particles were densely distributed, and their size was larger than that of nZVI-BC 3 (Figure 1 e). The results indicated that the $\mathrm{BC}$ reduced the aggregation of nanoparticles and effectively supported the nZVI.

The XRD analysis results for the $\mathrm{BC}$ and $\mathrm{nZVI}-\mathrm{BC}_{3}$ before and after the reaction are presented in Figure 2. The broad peak at $2 \theta=22.4^{\circ}$ indicates the presence of amorphous $B C[28,29]$, corresponding to a $d$-spacing of $0.4 \mathrm{~nm}$ according to Bragg's Law. The large $d$-spacing was attributed to the presence of $\mathrm{C}-\mathrm{O}$ and $\mathrm{O}=\mathrm{C}-\mathrm{O}$ [30]. For nZVI-BC 3 , the peak at $2 \theta=44.9^{\circ}$ confirmed the presence of $\mathrm{Fe}^{0}$ [31]. Furthermore, a peak at $22.4^{\circ}$ was observed, but the intensity was weakened, indicating that nZVI was successfully loaded in the pores of the BC. For the reacted $n Z V I-B_{3}$, characteristic peaks of $\mathrm{Fe}_{3} \mathrm{O}_{4}$ $\left(2 \theta=35.4^{\circ} / 57.2^{\circ}\right)$ and $\mathrm{Fe}_{2} \mathrm{O}_{3}\left(2 \theta=62.7^{\circ}\right)$ appeared [13]. The peak of $\mathrm{Fe} 0$ was still present, but was less pronounced than that for the fresh $\mathrm{nZVI}$, indicating that some of the $\mathrm{Fe}^{0}$ was consumed in the reaction. 


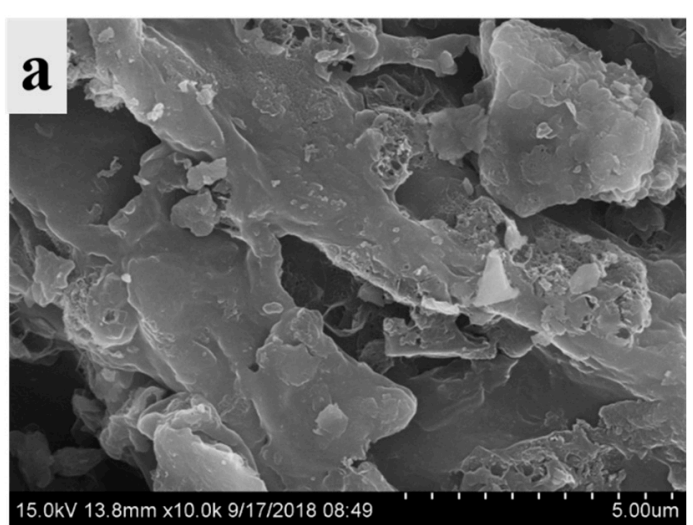

(a)

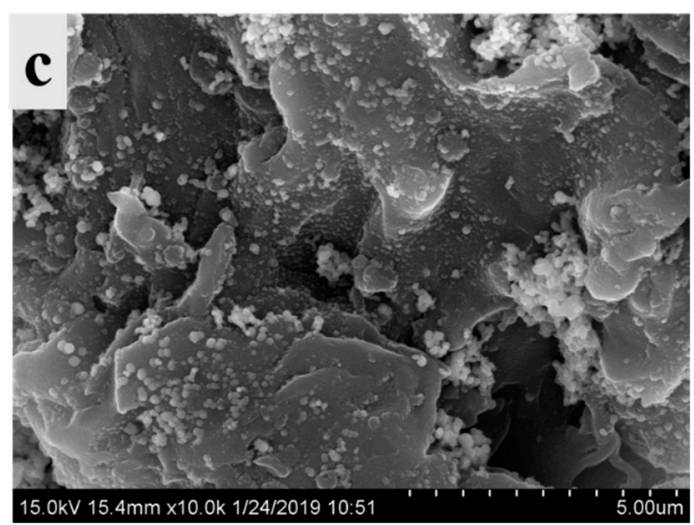

(c)

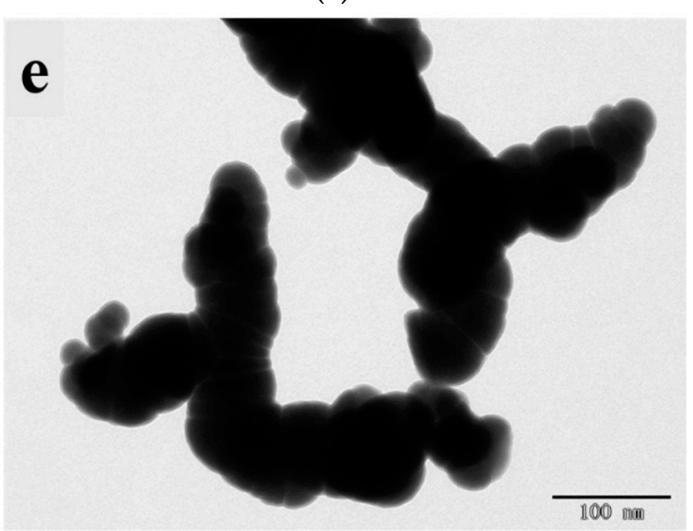

(e)

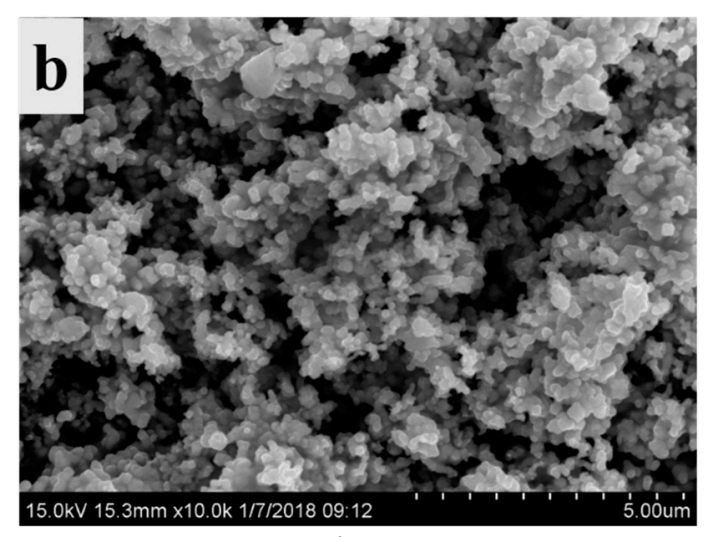

(b)

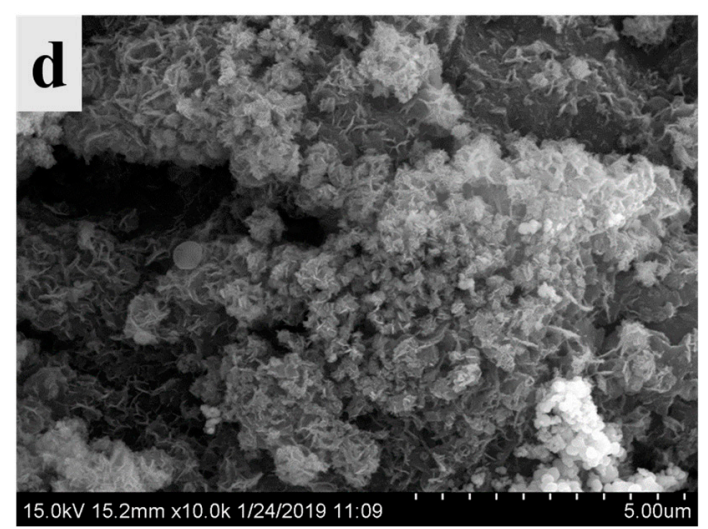

(d)

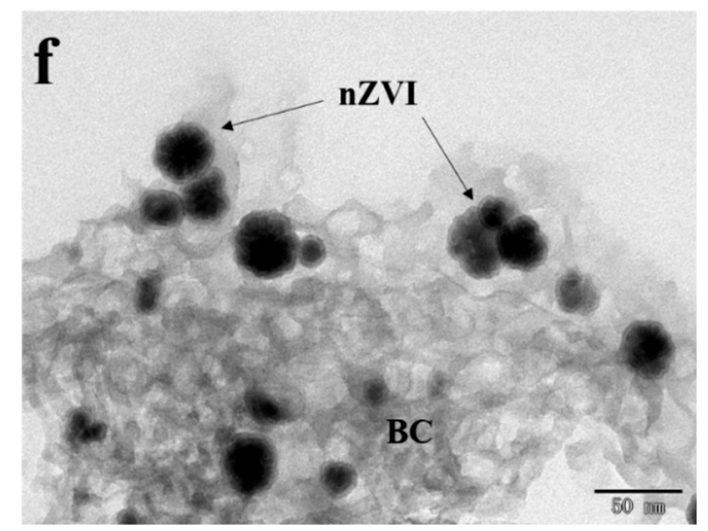

(f)

Figure 1. SEM images of biochar (BC) (a), nanoscale zero-valent iron (nZVI) (b), and nZVI-BC 3 before (c) and after (d) reaction. TEM images of $\mathrm{nZVI}(\mathbf{e})$ and $\mathrm{nZVI}-\mathrm{BC}_{3}(\mathbf{f})$. 


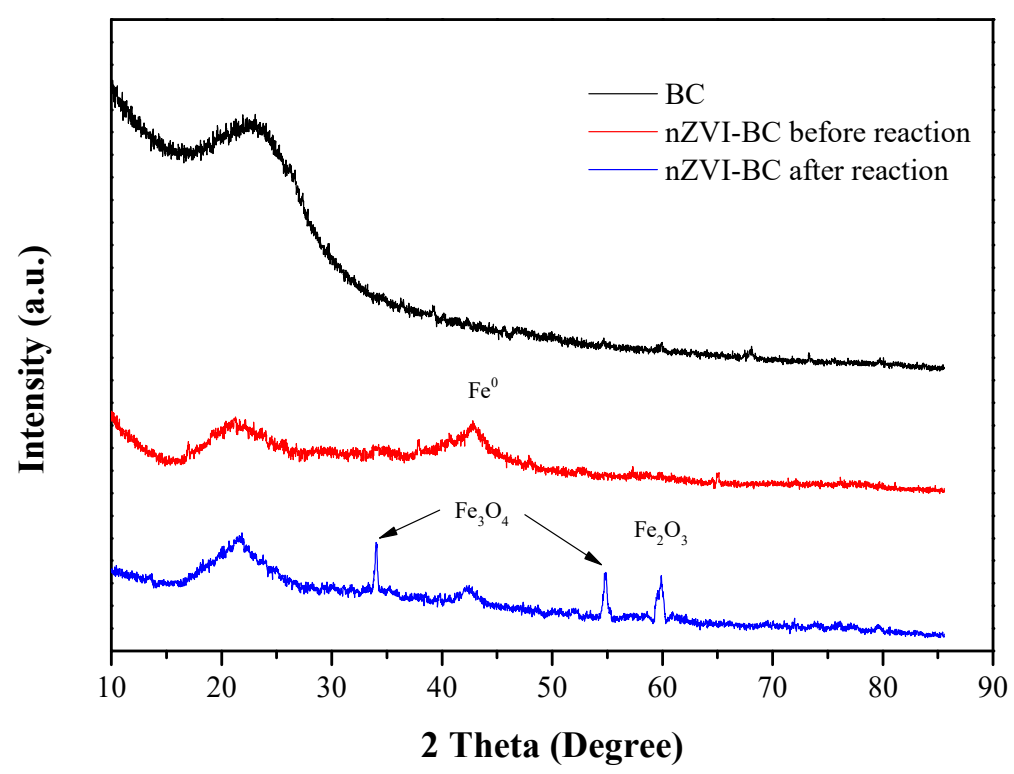

Figure 2. X-ray diffraction $(\mathrm{XRD})$ patterns of $\mathrm{BC}$, and $\mathrm{nZVI}-\mathrm{BC}_{3}$ before and after reaction.

Figure 3 presents the XPS patterns of nZVI-BC. For fresh nZVI-BC, the peaks at 706.9 and $720.2 \mathrm{eV}$ indicated the presence of $\mathrm{Fe}^{0}$ in nZVI-BC, and the peak at $711.1 \mathrm{eV}$ indicated $\mathrm{Fe}^{3+}\left(\mathrm{Fe}_{2} \mathrm{O}_{3}\right)$ [32]. These results suggest that the iron particles were covered by an oxide film, which formed a core-shell structure [33]. For the reacted nZVI-BC, the peaks at 711.1 and $725.1 \mathrm{eV}$ corresponded to $\mathrm{Fe}_{2} \mathrm{O}_{3}$. Moreover, the $\mathrm{O} 1 s$ feature peaks at $530 \mathrm{eV}$ in this region confirmed that $\mathrm{Fe}_{2} \mathrm{O}_{3}, \mathrm{Fe}_{3} \mathrm{O}_{4}$, and $\mathrm{FeOOH}$ all existed on the surface of nZVI before and after the reaction [34], and the iron hydroxides were dehydrated to oxides. These results indicate that the nZVI-BC was oxidized after the reaction, in accordance with Equations (5)-(8), which is consistent with the XRD results [13,35]. BC was mainly represented by $\mathrm{C} 1 \mathrm{~s}$ with a peak of $284.8 \mathrm{eV}$.

$$
\begin{gathered}
4 \mathrm{Fe}^{2+}+4 \mathrm{H}^{+}+\mathrm{O}_{2} \rightarrow 4 \mathrm{Fe}^{3+}+2 \mathrm{H}_{2} \mathrm{O} \\
\mathrm{Fe}^{3+}+2 \mathrm{H}_{2} \mathrm{O} \rightarrow \mathrm{FeOOH}+3 \mathrm{H}^{+} \\
2 \mathrm{FeOOH} \rightarrow \mathrm{Fe}_{2} \mathrm{O}_{3}+\mathrm{H}_{2} \mathrm{O} \\
6 \mathrm{Fe}^{2+}+\mathrm{O}_{2}+6 \mathrm{H}_{2} \mathrm{O} \rightarrow 2 \mathrm{Fe}_{3} \mathrm{O}_{4}+12 \mathrm{H}^{+}
\end{gathered}
$$
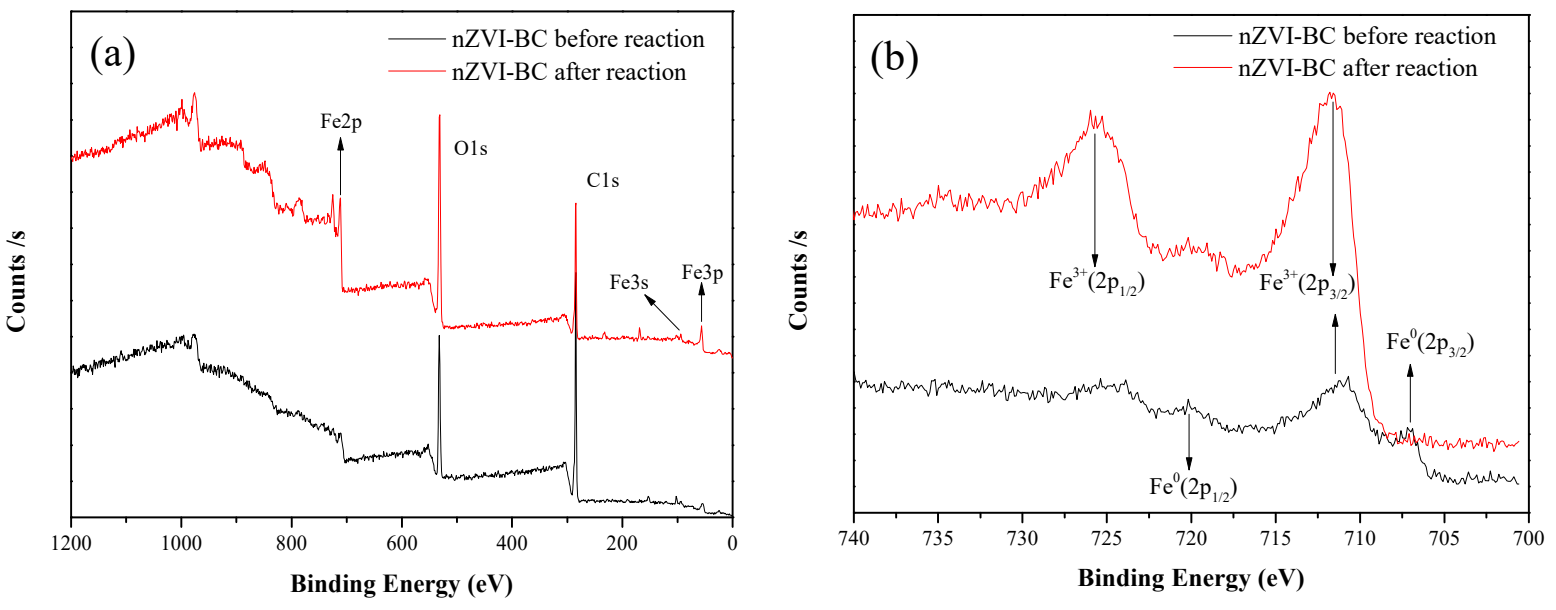

Figure 3. X-ray photoelectron spectroscopy (XPS) patterns from the full survey (a), and scan of Fe $2 p$ (b) for $\mathrm{nZVI}-\mathrm{BC}_{3}$ before and after reaction. 
The FTIR spectra of BC and nZVI-BC are presented in Figure 4. BC is a carbonaceous material with abundant functional groups [23]; therefore, many adsorption peaks were observed. The peaks at 1590 and $3430 \mathrm{~cm}^{-1}$ corresponded to aromatic $\mathrm{C}=\mathrm{C}$ and $-\mathrm{OH}$, respectively. The adsorption band at $1120 \mathrm{~cm}^{-1}$ corresponded to the stretching vibration of the $\mathrm{C}-\mathrm{O}$ bond. The signal at $592 \mathrm{~cm}^{-1}$ was the $\mathrm{Fe}-\mathrm{O}$ adsorption peak, which indicated that the nZVI was oxidized on the BC [36].

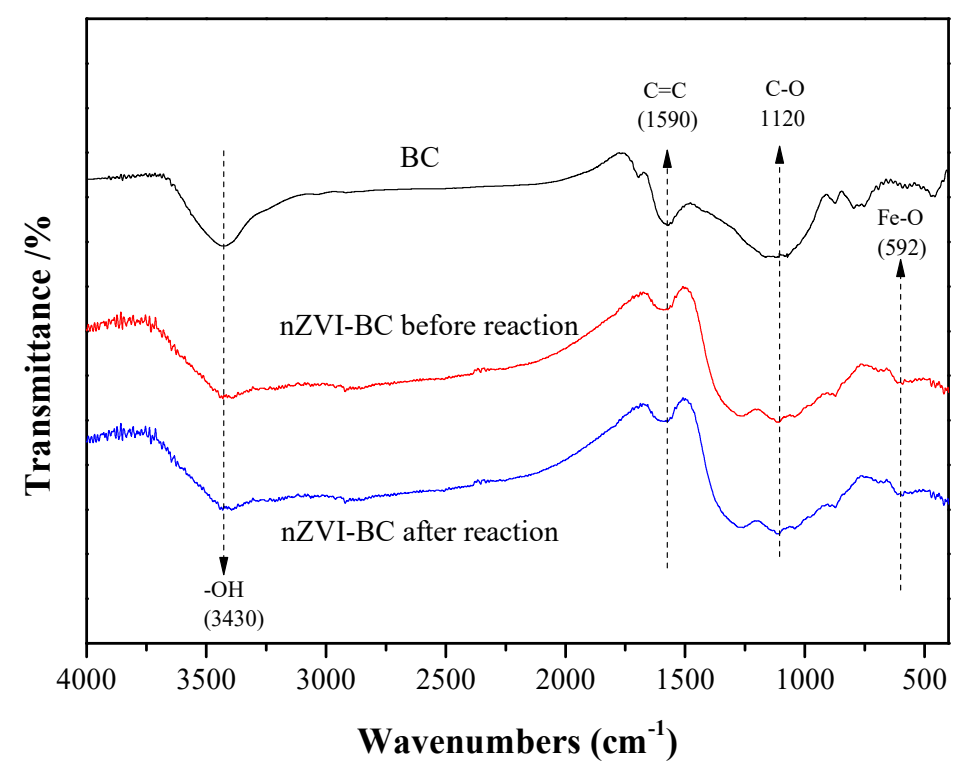

Figure 4. Fourier-transform infrared (FTIR) spectra of $\mathrm{BC}$, and $\mathrm{nZVI-BC} \mathrm{B}_{3}$ before and after reaction.

These functional groups were believed to play a crucial role in the adsorption of ONZ and the support of nZVI. These functional groups immobilized nZVI and reduced the electrostatic attraction with nZVI [36]. A previous study indicated that nitroimidazoles can be adsorbed onto organic matter through interactions between the $\pi$ electrons in the aromatic rings [37]. $B C$ had abundant $C=C$ and hydroxyl groups which acted as electron donors in the $\pi-\pi$ aromatic interactions [33], while the nitro groups of ONZ acted as $\pi$-electron acceptors [38]. The $\pi-\pi$ interactions enhanced the transfer of ONZ onto the surface of the $\mathrm{BC}$, which increased the contact of ONZ and nZVI-BC.

\subsection{Degradation of ONZ in Different Systems}

To examine the role of different materials, experiments were conducted in different systems, including $\mathrm{BC}, \mathrm{nZVI}$, and different nZVI-BC samples without $\mathrm{H}_{2} \mathrm{O}_{2}$. According to previous reports, ONZ is stable at a $\mathrm{pH}<6$ [8], and the result of the blank experiment was not presented. As shown in Figure $5 \mathrm{a}$, the removal efficiency of ONZ was $45.8 \%$ in the nZVI system over $12 \mathrm{~min}$, and the results were consistent with previous reports indicating that ONZ can be degraded by nZVI [39]. For the nZVI-BC system, the removal efficiency increased from $55.7 \%$ to $74.9 \%$ with an increase in the nZVI to $\mathrm{BC}$ mass ratio from 2:1 to 1:2. The results indicated that the $\mathrm{BC}$ played an important role in enhancing the activity of the nZVI [33]. As shown in Table 1, the BC had a larger specific surface area and total pore volume than the $\mathrm{nZVI}$, and the attachment of the $\mathrm{nZVI}$ on the BC increased the dispersion and reduced the aggregation. Accordingly, the removal efficiency increased as the number of active sites increased. However, with a further increase in the mass ratio to $1: 3$, the removal efficiency decreased to $64.7 \%$. This may be because the nZVI particles were enclosed by the excess BC $[23,26]$, which hindered the contact of nZVI and ONZ. 

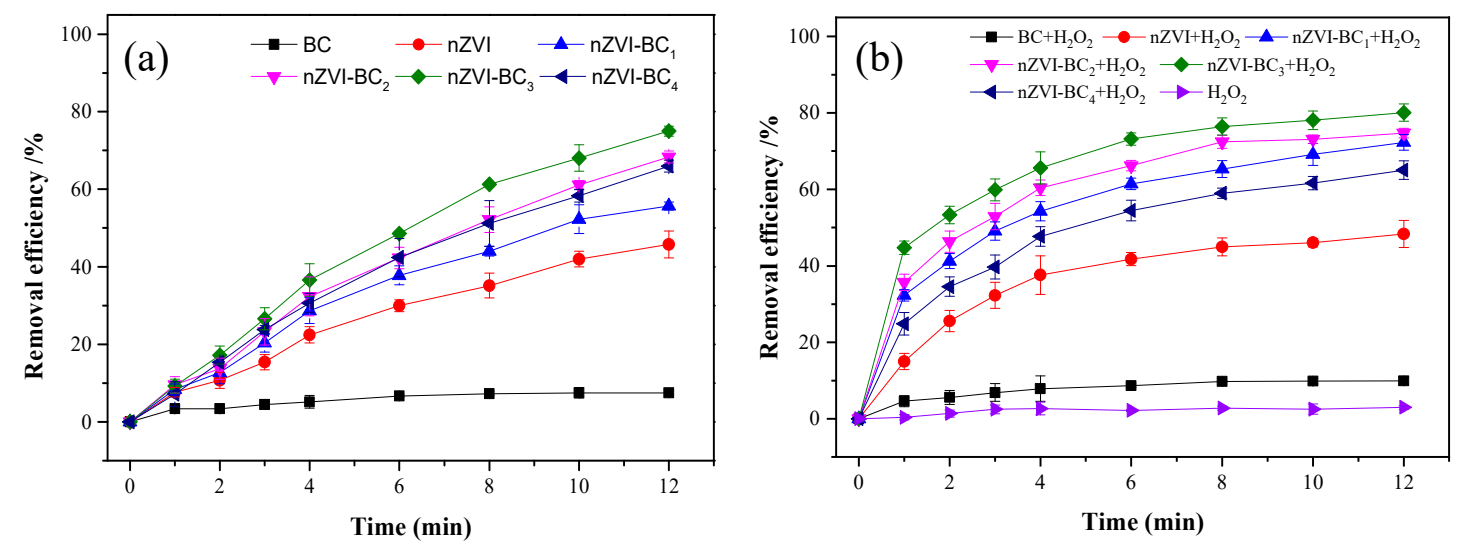

Figure 5. Comparison of ornidazole (ONZ) degradation for different systems: without $\mathrm{H}_{2} \mathrm{O}_{2}$ (a) and with $\mathrm{H}_{2} \mathrm{O}_{2}(\mathbf{b})$. Operating conditions: $\mathrm{C}_{0}=100 \mathrm{mg} / \mathrm{L}, \mathrm{pH}=3.0, \mathrm{~T}=25^{\circ} \mathrm{C},\left[\mathrm{H}_{2} \mathrm{O}_{2}\right]_{0}=12 \mathrm{mM}$; $\mathrm{BC}=0.2 \mathrm{~g} / \mathrm{L} ; \mathrm{nZVI}=0.1 \mathrm{~g} / \mathrm{L} ; \mathrm{nZVI}-\mathrm{BC}_{1}=0.15 \mathrm{~g} / \mathrm{L}$ (mass ratio of $2: 1$ ); $\mathrm{nZVI}-\mathrm{BC}_{2}=0.2 \mathrm{~g} / \mathrm{L}$ (mass ratio of

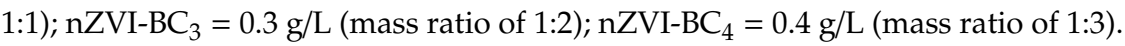

In the experiment, approximately $7.5 \%$ of the $\mathrm{ONZ}$ in the $\mathrm{BC}$ was removed owing to the adsorption property of the $\mathrm{BC}$. The variation of the $\mathrm{pH}$ in the degradation process was measured (Figure S1, Supplementary Materials). The $\mathrm{pH}$ increased from 3.0 to a final value of 3.5, indicating the corrosion of iron (Equation (9)). The $\mathrm{pK}_{\mathrm{a}}$ value of the ONZ was 2.4 [40]. The ONZ was deprotonated and existed as an anionic species in the experiments. All the $\mathrm{pH}_{\mathrm{PZC}}$ values of the catalysts were significantly higher than 3.5, and the surface was positively charged. Thus, the electrostatic interactions between the positively charged materials and anionic ONZ involved an attractive force. The adsorption behavior of the ONZ was mainly attributed to the $\pi-\pi$ interactions and electrostatic attraction in our experiments, and the former was discussed in Section 3.1.

$$
\mathrm{Fe}+2 \mathrm{H}^{+} \rightarrow \mathrm{Fe}^{2+}+\mathrm{H}_{2} .
$$

Figure $5 \mathrm{~b}$ shows the degradation of $\mathrm{ONZ}$ in the $\mathrm{BC}, \mathrm{nZVI}$, and different nZVI-BC composites in the presence of $\mathrm{H}_{2} \mathrm{O}_{2}$. The decomposition of $\mathrm{ONZ}$ was $2.2 \%$ in the $\mathrm{H}_{2} \mathrm{O}_{2}$ system, and approximately $9.9 \%$ of the ONZ in the $\mathrm{BC} / \mathrm{H}_{2} \mathrm{O}_{2}$ system was eliminated, indicating that the $\mathrm{BC}$ was insufficient to induce $\mathrm{H}_{2} \mathrm{O}_{2}$ decomposition. For the $n Z V I / \mathrm{H}_{2} \mathrm{O}_{2}$ system, $\mathrm{H}_{2} \mathrm{O}_{2}$ was activated with $48.3 \% \mathrm{ONZ}$ removal. In contrast, the application of nZVI-BC enhanced the activation of $\mathrm{H}_{2} \mathrm{O}_{2}$, and $>63 \%$ of the ONZ was removed in $12 \mathrm{~min}$. The ONZ removal efficiencies were $72.3 \%, 76.6 \%, 75 \%, 80.1 \%$, and $63.8 \%$ for nZVI/BC mass ratios of 2:1, 1:1, 1:2, and 1:3, respectively. Compared with nZVI, nZVI-BC had a larger surface area, which was beneficial for the distribution of nZVI and the adsorption of ONZ. Thus, the removal efficiency increased with the number of active sites. The results also indicated that $\mathrm{nZVI-BC} \mathrm{B}_{3}$ exhibited the highest removal efficiency; high $\mathrm{BC}$ content in $\mathrm{nZVI-BC}{ }_{4}$ may cause the aggregation of $B C$ sheets, which covered the reactive sites on the surface, reducing the removal efficiency $[23,26]$. Therefore, $\mathrm{nZVI}-\mathrm{BC}_{3}$ was selected as the optimal composite in the subsequent experiments.

Although high ONZ removal efficiencies were obtained for both the nZVI-BC and nZVI-BC/ $\mathrm{H}_{2} \mathrm{O}_{2}$ systems, more COD and TOC were removed in nZVI-BC/ $\mathrm{H}_{2} \mathrm{O}_{2}$ than in nZVI-BC (Figure S2, Supplementary Materials). This may be because reduction was the removal mechanism in the nZVI-BC system [40], whereas, in the nZVI-BC/ $\mathrm{H}_{2} \mathrm{O}_{2}$ system, a large number of carbon atoms in the ONZ molecules were converted into $\mathrm{CO}_{2}$ [7]. Similar results were obtained in previous studies [13]. Thus, nZVI-BC/ $\mathrm{H}_{2} \mathrm{O}_{2}$ was selected as the optimal candidate system in this study. 


\subsection{Effects of Different Parameters on Degradation of ONZ}

\subsubsection{Effect of Initial $\mathrm{pH}$}

As shown in Figure 6a the degradation was significantly affected by the solution $\mathrm{pH}$, and the optimal $\mathrm{pH}$ was 3.0. The removal efficiencies were $74.7 \%$ and $80.1 \%$ when the $\mathrm{pH}$ was 2.0 and 3.0, respectively. When the $\mathrm{pH}$ was $<3.0, \mathrm{H}^{+}$atoms acted as $\bullet \mathrm{OH}$ scavengers [41], and $\mathrm{H}_{2} \mathrm{O}_{2}$ was solvated to form a stable oxonium ion when a large number of $\mathrm{H}^{+}$ions existed [42,43]. Consequently, the degradation efficiency at a $\mathrm{pH}$ of 2.0 was lower than that at a $\mathrm{pH}$ of 3.0. The removal efficiency decreased significantly as the initial $\mathrm{pH}$ increased. When the $\mathrm{pH}$ increased to 4.0 and 5.0, the ONZ removal efficiency decreased to $61.1 \%$ and $40.3 \%$, respectively. At a $\mathrm{pH}$ of 6.0, no significant removal of ONZ was observed. Possible reasons for the foregoing findings are manifold. Firstly, the corrosion of $\mathrm{Fe}^{0}$ was faster and easier at lower $\mathrm{pH}$ values [32], which increased the concentration of $\mathrm{Fe}^{2+}$ and generated more $\bullet \mathrm{OH}$. Secondly, the oxidation potential of $\bullet \mathrm{OH}$ was significantly influenced by the solution $\mathrm{pH}$. At a higher $\mathrm{pH}$, the oxidation ability of $\bullet \mathrm{OH}$ was reduced [44]. Thirdly, the hydrolysis of iron ion at higher $\mathrm{pH}$ also had adverse effects on the formation of hydroxyl radicals due to the precipitation of FeOOH on the surface of nZVI $[45,46]$. Lastly, the iron-peroxo complex, which was the intermediate of Fenton reaction, becomes more stable with increasing $\mathrm{pH}$ and might yield less $\bullet \mathrm{OH}$ for the degradation [47].
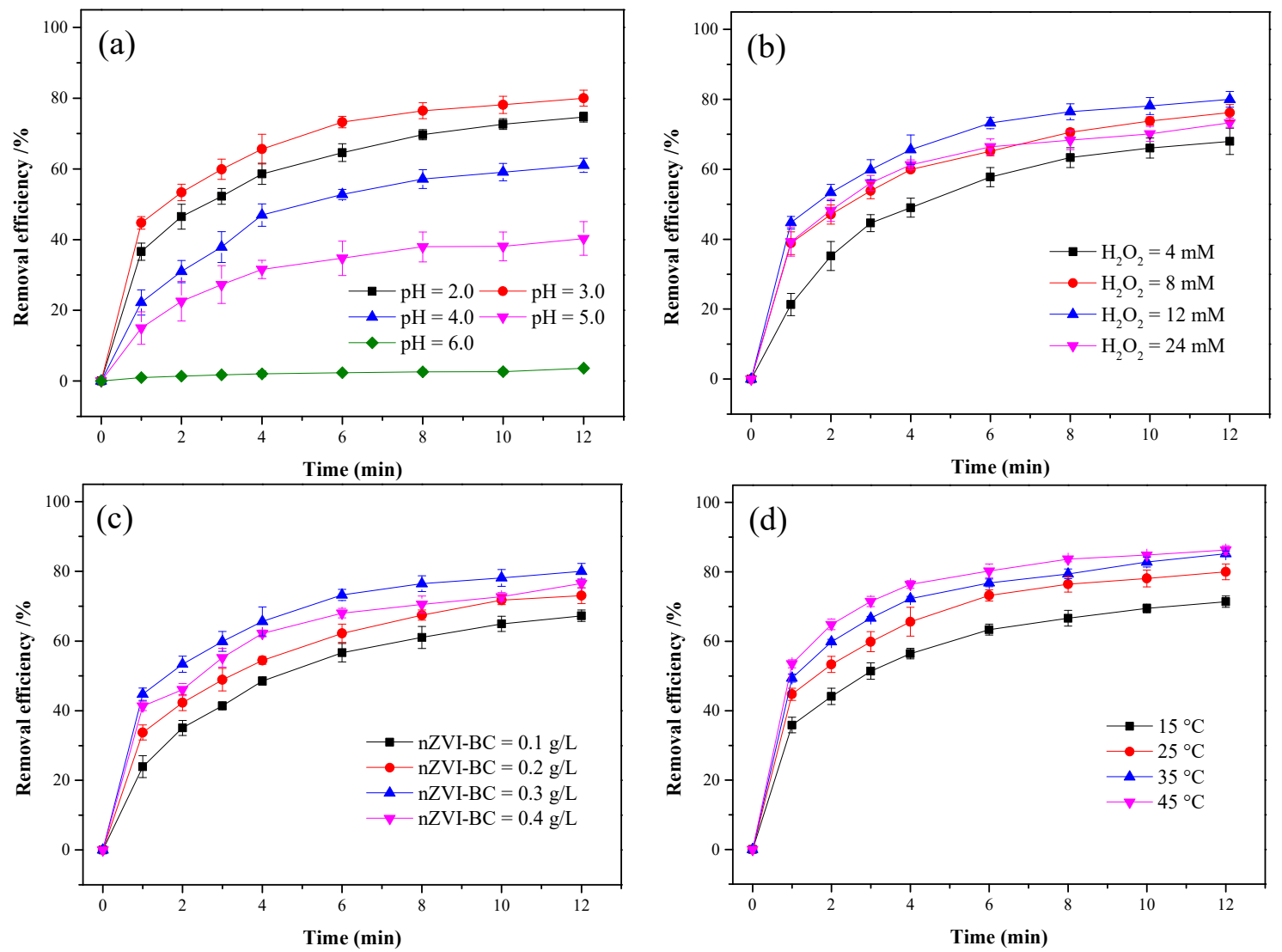

Figure 6. Effects of factors on the degradation of ONZ by nZVI-BC/ $\mathrm{H}_{2} \mathrm{O}_{2}$ : (a) initial $\mathrm{pH} ;(\mathbf{b}) \mathrm{H}_{2} \mathrm{O}_{2}$ concentration; (c) nZVI-BC dose; (d) temperature. Except for the investigated parameter, other operation parameters were fixed as $\mathrm{C}_{0}=100 \mathrm{mg} / \mathrm{L}, \mathrm{T}=25^{\circ} \mathrm{C}, \mathrm{pH}=3.0,\left[\mathrm{H}_{2} \mathrm{O}_{2}\right]_{0}=12 \mathrm{mM}$, and nZVI-BC $3=0.3 \mathrm{~g} / \mathrm{L}$.

In conclusion, the $\mathrm{pH}$ significantly influenced the Fenton-like processes by controlling the catalytic activity of the iron species and the stability of $\mathrm{H}_{2} \mathrm{O}_{2}$ [41]. 


\subsubsection{Effect of Initial $\mathrm{H}_{2} \mathrm{O}_{2}$ Concentration}

The effects of different initial $\mathrm{H}_{2} \mathrm{O}_{2}$ concentrations within the range of 4-24 mM were investigated. As shown in Figure $6 \mathrm{~b}, \mathrm{H}_{2} \mathrm{O}_{2}$ played a dual role in the degradation of ONZ. The ONZ removal efficiency increased from $68.1 \%$ to $80.1 \%$ when the $\mathrm{H}_{2} \mathrm{O}_{2}$ concentration increased from 4 to $12 \mathrm{mM}$, and it decreased from $80.1 \%$ to $73.3 \%$ when the $\mathrm{H}_{2} \mathrm{O}_{2}$ concentration increased from 12 to $24 \mathrm{mM}$. These results are consistent with previous reports [48]. At a low $\mathrm{H}_{2} \mathrm{O}_{2}$ concentration, the produced hydroxyl radicals were insufficient. With an increase in the initial $\mathrm{H}_{2} \mathrm{O}_{2}$ concentration, more $\mathrm{H}_{2} \mathrm{O}_{2}$ molecules could contact the nZVI-BC, leading to the generation of more $\bullet \mathrm{OH}$; thus, the removal efficiency increased. However, with excessive $\mathrm{H}_{2} \mathrm{O}_{2}$, excess $\mathrm{H}_{2} \mathrm{O}_{2}$ reacted with $\bullet \mathrm{OH}$ and produced $\mathrm{HO}_{2} \bullet$ and $\mathrm{O}_{2} \bullet$ in accordance with Equations (10)-(12), which were more selective than $\bullet \mathrm{OH}$ [49]. Therefore, the optimal $\mathrm{H}_{2} \mathrm{O}_{2}$ concentration for ONZ removal was $12 \mathrm{mM}$ in the nZVI-BC/ $\mathrm{H}_{2} \mathrm{O}_{2}$ system.

$$
\begin{gathered}
\bullet \mathrm{OH}+\mathrm{H}_{2} \mathrm{O}_{2} \rightarrow \mathrm{OH}_{2} \bullet / \mathrm{O}_{2} \bullet+\mathrm{H}_{2} \mathrm{O} . \\
\mathrm{HO}_{2} \bullet+\bullet \mathrm{OH} \rightarrow \mathrm{H}_{2} \mathrm{O}+\mathrm{O}_{2} . \\
\bullet \mathrm{OH}+\bullet \mathrm{OH} \rightarrow \mathrm{H}_{2} \mathrm{O}_{2} .
\end{gathered}
$$

\subsubsection{Effect of nZVI-BC dose}

The effect of the nZVI-BC dose on the degradation of ONZ is shown in Figure 6c. The removal efficiency after $12 \mathrm{~min}$ increased from $67.2 \%$ to $80.1 \%$ when the dose increased from 0.1 to $0.3 \mathrm{~g} / \mathrm{L}$. However, with a further increase in the dose to $0.4 \mathrm{~g} / \mathrm{L}$, the removal efficiency decreased to $76.5 \%$. The Fenton reaction was significantly affected by the ferrous irons provided by $\mathrm{Fe}^{0}$, which plays a major role in the formation of hydroxyl radicals $[50,51]$. The number of active sites increased with an increase in the nZVI-BC dose within the range of $0.1-0.3 \mathrm{~g} / \mathrm{L}$, leading to the release of more $\mathrm{Fe}^{2+}$ to react with $\mathrm{H}_{2} \mathrm{O}_{2}$ and the generation more $\bullet \mathrm{OH}$, which improved the removal efficiency. When the nZVI-BC dose further increased to $0.4 \mathrm{~g} / \mathrm{L}$, the ONZ removal efficiency may have decreased owing to the $\bullet \mathrm{OH}$ scavenging effect of extra nZVI-BC through an undesirable reaction (Equation (13)) [14]. Consequently, the optimal nZVI-BC dose was $0.3 \mathrm{~g} / \mathrm{L}$ in this study.

$$
\mathrm{Fe}^{2+}+\bullet \mathrm{OH} \rightarrow \mathrm{Fe}^{3+}+\mathrm{OH}^{-} .
$$

\subsubsection{Effect of Temperature}

The effect of the temperature was also investigated, and the results are shown in Figure $6 \mathrm{~d}$. The general trend was that increasing the temperature enhanced the removal of ONZ. The degradation efficiency increased from $71.4 \%$ to $86.3 \%$ when the temperature increased from 15 to $45^{\circ} \mathrm{C}$. A high temperature promoted the production of hydroxyl radicals [52] and enhanced the contact of ONZ molecules with nZVI-BC [53], leading to a higher degradation efficiency.

\subsubsection{Kinetics Study}

According to previous studies [13,35], two kinetic models were used to analyze the organic compound degradation in the Fenton-like reaction (Figure S3, Supplementary Materials).

Pseudo-first-order reaction:

$$
\ln \left(\frac{C_{t}}{C_{0}}\right)=-k_{1} t
$$

Pseudo-second-order reaction:

$$
\frac{1}{\mathrm{C}_{\mathrm{t}}}-\frac{1}{\mathrm{C}_{0}}=\mathrm{k}_{2} \mathrm{t} .
$$

Here, $\mathrm{k}_{1}\left(\mathrm{~min}^{-1}\right)$ and $\mathrm{k}_{2}\left(\mathrm{~L} \cdot \mathrm{mg}^{-1} \cdot \mathrm{min}^{-1}\right)$ represent the kinetic rate constants of the pseudo-first-order and pseudo-second-order reactions, respectively, and $C_{0}$ and $C_{t}$ represent the concentrations of ONZ 
$(\mathrm{mg} / \mathrm{L})$ at time $\mathrm{t}=0$ and at time $\mathrm{t}(\mathrm{min})$, respectively. The $\mathrm{k}$ values are presented in Table 2 . The results indicated that the pseudo-second-order reaction model was more suitable for describing the degradation process $\left(R^{2}>0.95\right)$. The kinetic rate constants increased as the temperature increased. The activation energy of ONZ degradation was calculated using the Arrhenius equation.

$$
\ln \mathrm{k}=-\frac{\mathrm{E}_{\mathrm{a}}}{\mathrm{RT}}+\ln \mathrm{A}
$$

where $\mathrm{k}\left(\mathrm{L} \cdot \mathrm{mg}^{-1} \cdot \mathrm{min}^{-1}\right)$ represents the rate constant, $\mathrm{E}_{\mathrm{a}}$ represents the Arrhenius activation energy $(\mathrm{kJ} / \mathrm{mol})$, A represents the Arrhenius factor, $\mathrm{R}$ represents the gas constant $(8.314 \mathrm{~J} /(\mathrm{mol} \mathrm{K}))$, and $\mathrm{T}$ represents the temperature. The Ea was calculated as $24.1 \mathrm{~kJ} / \mathrm{mol}$, indicating that the degradation of ONZ was a diffusion-controlled reaction [13]. It can be concluded that the degradation of ONZ in the $\mathrm{nZVI-BC} / \mathrm{H}_{2} \mathrm{O}_{2}$ was easily achieved owing to the relatively low activation energy [54].

Table 2. The degradation rate constants and $R^{2}$ for different kinetic models. Operating conditions: $\mathrm{C}_{0}=100 \mathrm{mg} / \mathrm{L}, \mathrm{pH}=3.0, \mathrm{~T}=25^{\circ} \mathrm{C},\left[\mathrm{H}_{2} \mathrm{O}_{2}\right]_{0}=12 \mathrm{mM}, \mathrm{nZVI}-\mathrm{BC}_{3}=0.3 \mathrm{~g} / \mathrm{L}$.

\begin{tabular}{|c|c|c|c|c|}
\hline \multirow{2}{*}{$\mathrm{T}\left({ }^{\circ} \mathrm{C}\right)$} & \multicolumn{2}{|c|}{ Pseudo-First-Order Model } & \multicolumn{2}{|c|}{ Pseudo-Second-Order Model } \\
\hline & $k_{1}\left(\min ^{-1}\right)$ & $R^{2}$ & $\mathrm{k}_{2}\left(\mathrm{~L} \cdot \mathrm{mg}^{-1} \cdot \mathrm{min}^{-1}\right)$ & $R^{2}$ \\
\hline 15 & 0.1033 & 0.8562 & 0.0021 & 0.9568 \\
\hline 25 & 0.1336 & 0.8536 & 0.0035 & 0.9689 \\
\hline 35 & 0.1482 & 0.8316 & 0.0045 & 0.9737 \\
\hline 45 & 0.1605 & 0.8051 & 0.0055 & 0.9651 \\
\hline
\end{tabular}

\subsection{Stability and Reusability of $n Z V I-B C$}

The stability of nZVI-BC was investigated through an experiment involving consecutive cycles under the same conditions. After each cycle, the nZVI-BC was collected via vacuum filtration and washed several times for further use. As shown in Figure 7, the removal efficiency decreased from $80.1 \%$ to $63.2 \%$ after three recycling runs, owing to the release and consumption of $\mathrm{Fe}^{0}$ from nZVI-BC $[23,24]$. However, this was still a good value considering that a high concentration of the ONZ solution was treated in the experiments. In the future, efforts should be directed toward reducing the iron leaching and improving the recycling performance of $\mathrm{nZVI-BC} / \mathrm{H}_{2} \mathrm{O}_{2}$ systems.

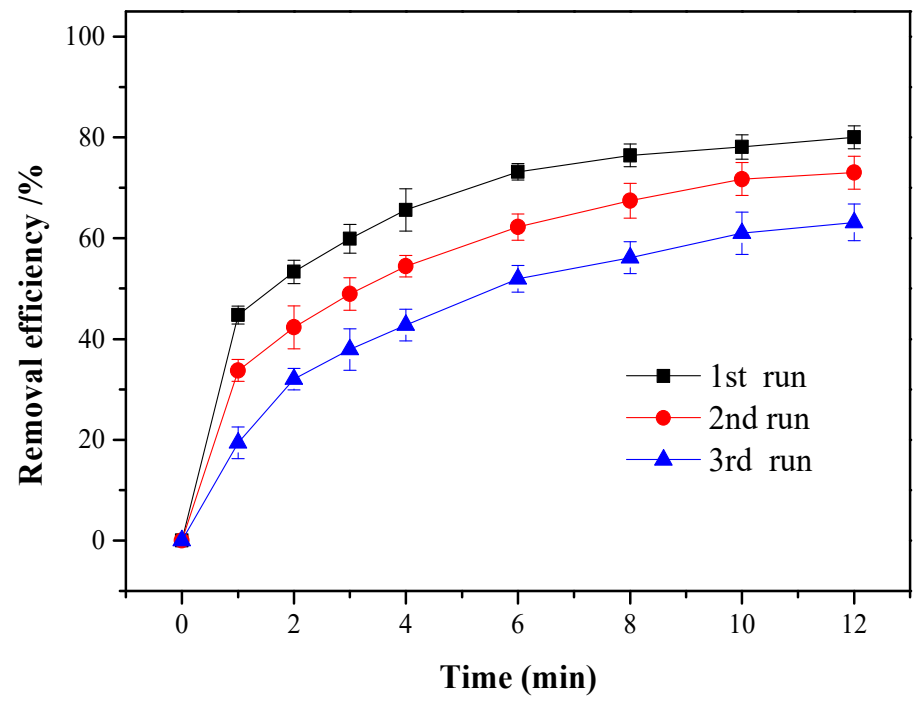

Figure 7. The recycling degradation of $\mathrm{ONZ}$ by the $\mathrm{nZVI-BC} / \mathrm{H}_{2} \mathrm{O}_{2}$ system. Operating conditions: $\mathrm{C}_{0}=100 \mathrm{mg} / \mathrm{L}, \mathrm{pH}=3.0, \mathrm{~T}=25^{\circ} \mathrm{C},\left[\mathrm{H}_{2} \mathrm{O}_{2}\right]_{0}=12 \mathrm{mM}, \mathrm{nZVI}-\mathrm{BC}_{3}=0.3 \mathrm{~g} / \mathrm{L}$. 


\subsection{Possible Oxidation Degradation Mechanism}

The role of $\bullet \mathrm{OH}$ in the degradation of ONZ was examined by conducting a control experiment in an $\mathrm{H}_{2} \mathrm{O}_{2}$ system with the presence of TBA. As shown in Figure 8, the removal efficiency decreased significantly with an increase in the TBA concentration. TBA is a good $\bullet \mathrm{OH}$ scavenger and captures $\bullet \mathrm{OH}$ during the Fenton reaction [55]. The removal of ONZ was almost completely inhibited with $0.5 \mathrm{~mL}$ of TBA. Therefore, the $\bullet \mathrm{OH}$ played a decisive role in the oxidation of ONZ.

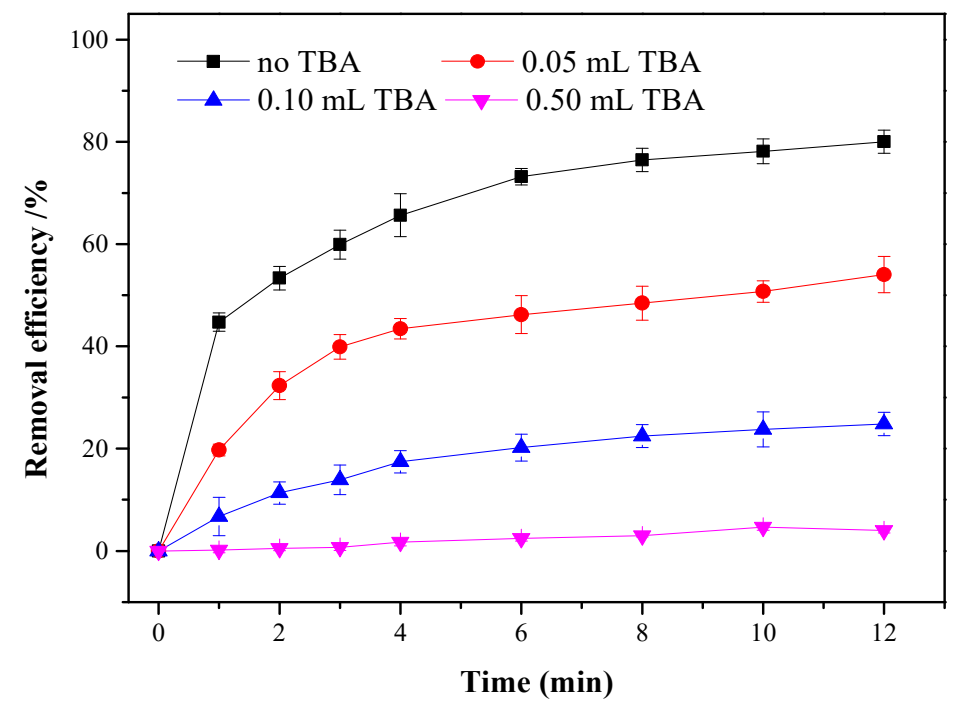

Figure 8. Degradation of ONZ with different tert-butyl alcohol (TBA) addition. Operating conditions: $\mathrm{C}_{0}=100 \mathrm{mg} / \mathrm{L}, \mathrm{pH}=3.0, \mathrm{~T}=25^{\circ} \mathrm{C},\left[\mathrm{H}_{2} \mathrm{O}_{2}\right]_{0}=12 \mathrm{mM}, \mathrm{nZVI}-\mathrm{BC}_{3}=0.3 \mathrm{~g} / \mathrm{L}$.

The UV-Vis spectrum of ONZ oxidation removal is presented in Figure 9. The characteristic absorption band of ONZ was approximately $318 \mathrm{~nm}$ and decreased with the increasing reaction time. A new adsorption band between 260 and $280 \mathrm{~nm}$ appeared and decreased, which may correspond to intermediates [56]. Furthermore, the peak between 220 and $240 \mathrm{~nm}$ increased significantly after the reaction started and remained relatively stable during the reaction, possibly indicating the formation of final products.

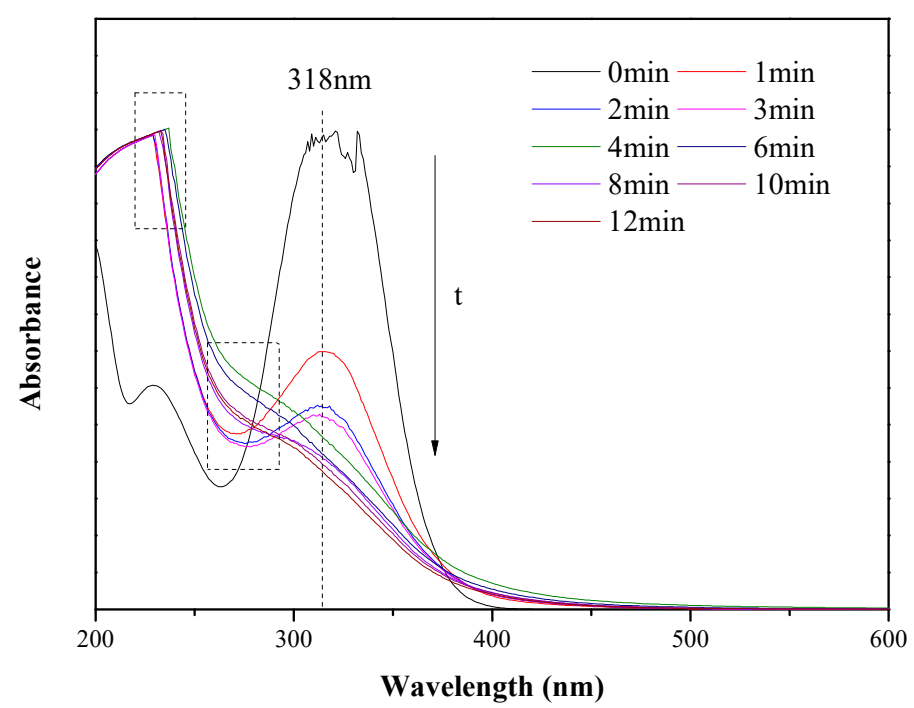

Figure 9. Ultraviolet-visible light (UV-Vis) spectrum of ONZ at various times. Operating conditions: $\mathrm{C}_{0}=100 \mathrm{mg} / \mathrm{L}, \mathrm{pH}=3.0, \mathrm{~T}=25^{\circ} \mathrm{C},\left[\mathrm{H}_{2} \mathrm{O}_{2}\right]_{0}=12 \mathrm{mM}, \mathrm{nZVI}-\mathrm{BC}_{3}=0.3 \mathrm{~g} / \mathrm{L}$. 
Nitrite, nitrate, and chloride ions were detected in the solution after the reaction (Figure S4, Supplementary Materials), indicating that these ions were formed in the oxidation process. The $\mathrm{NO}_{2}{ }^{-}$ ions are attributed to the N-denitration via radical attack [57], and they were released by radical substitution [31]. The $\mathrm{NO}_{3}{ }^{-}$ions may have been related to the opening of the imidazole ring [57]. The $\mathrm{Cl}^{-}$ions may have come from the formation of ornidazole epoxide via the attack of $\bullet \mathrm{OH}$ on the ONZ [7] or the hydrogen chloride cleavage in the process of oxidation [8]. $\bullet \mathrm{OH}$ is a strongly active non-selective agent, which was likely responsible for the scission of the $\mathrm{C}-\mathrm{N}$ and $\mathrm{C}-\mathrm{C}$ bonds [7]. According to these results, plausible pathways are proposed in Figure 10.

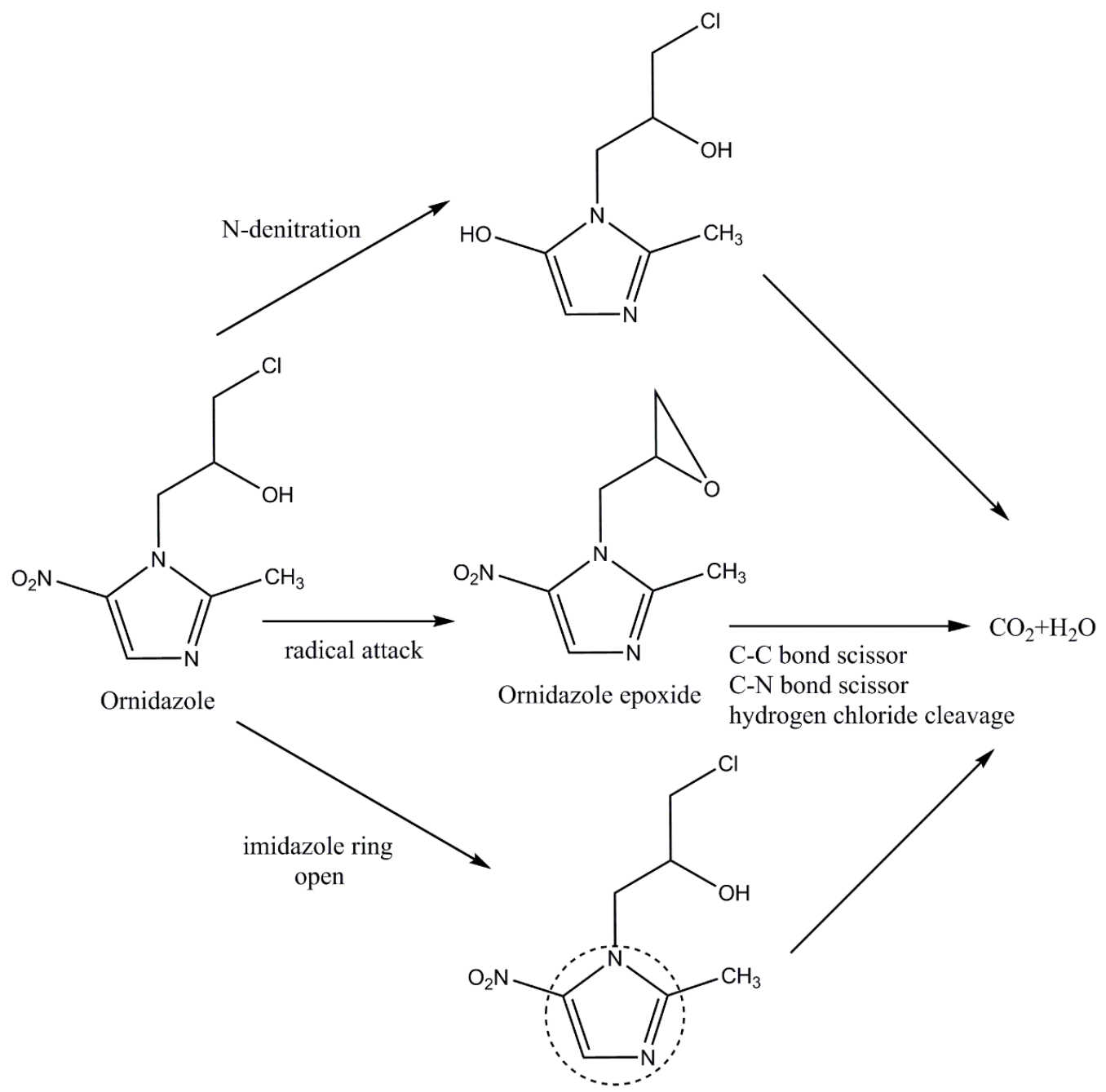

Figure 10. Possible pathways of ONZ degradation in the $\mathrm{nZVI-BC} / \mathrm{H}_{2} \mathrm{O}_{2}$ system.

On the basis of these analyses, a possible mechanism of ONZ degradation in the nZVI-BC/ $/ \mathrm{H}_{2} \mathrm{O}_{2}$ system is proposed. Firstly, the ONZ molecules were adsorbed onto the surface of nZVI-BC, and then $\mathrm{Fe}^{2+}$ was formed on the surface of iron nanoparticles via the corrosion of $\mathrm{Fe}^{0}$. Secondly, the $\mathrm{H}_{2} \mathrm{O}_{2}$ was activated by $\mathrm{Fe}^{2+}$, and highly reactive $\bullet \mathrm{OH}$ was produced continuously. Finally, the $\bullet \mathrm{OH}$ attacked the ONZ, and a part of the ONZ was mineralized into $\mathrm{CO}_{2}$ and $\mathrm{H}_{2} \mathrm{O}$ on the surface of nZVI-BC. Meanwhile, $\mathrm{Fe}^{3+}$ in the solution was gradually turned back and formed an oxidation layer on the $\mathrm{Fe}^{0}$ surface. In the process, the adsorption capacity and support ability of $\mathrm{BC}$ were fully exploited to improve the removal efficiency of ONZ.

Thus, the removal of ONZ can be described as follows: 
(1) Adsorption of ONZ on nZVI-BC

$$
\mathrm{nZVI}-\mathrm{BC}+\mathrm{ONZ} \rightarrow \mathrm{nZVI}-\mathrm{BC}-\mathrm{ONZ}
$$

(2) Generation of hydroxyl radicals

$$
\begin{gathered}
\mathrm{Fe}+2 \mathrm{H}^{+} \rightarrow \mathrm{Fe}^{2+}+\mathrm{H}_{2} . \\
\mathrm{Fe}^{2+}+\mathrm{H}_{2} \mathrm{O}_{2} \rightarrow \mathrm{Fe}^{3+}+\bullet \mathrm{OH}+\mathrm{OH}^{-} \\
2 \mathrm{Fe}^{3+}+\mathrm{Fe} \rightarrow 3 \mathrm{Fe}^{2+}
\end{gathered}
$$

(3) Reaction of ONZ and hydroxyl radicals

$$
\begin{gathered}
\mathrm{ONZ}+\bullet \mathrm{OH} \rightarrow \text { intermediates. } \\
\text { intermediates }+\bullet \mathrm{OH} \rightarrow \mathrm{CO}_{2}+\mathrm{H}_{2} \mathrm{O} .
\end{gathered}
$$

\section{Conclusions}

In this study, nZVI-BC was used as an activator for the Fenton-like oxidation of ONZ. Compared with $\mathrm{nZVI}$ and BC, the nZVI-BC had the highest removal efficiency for ONZ. The presence of BC in nZVI-BC not only enhanced the adsorption of ONZ but also provided more active sites. The results indicated that $\mathrm{nZVI}-\mathrm{BC}_{3}$ (nZVI:BC $=1: 2$ ), which had the highest BET surface area, exhibited the best degradation performance among the samples tested. The effects of the initial $\mathrm{pH}, \mathrm{H}_{2} \mathrm{O}_{2}$ concentration, nZVI-BC dose, and temperature on the degradation performance were examined in detail, and the degradation of ONZ followed a pseudo-second-order kinetics model $\left(R^{2}>0.95\right)$. The stability of nZVI-BC was also investigated, which exhibited a good performance even after three recycling runs. The mechanism of ONZ degradation involved the activation of $\mathrm{H}_{2} \mathrm{O}_{2}$ by nZVI-BC to generate $\bullet \mathrm{OH}$ and the mineralization of $\mathrm{ONZ}$ into $\mathrm{CO}_{2}$ and $\mathrm{H}_{2} \mathrm{O}$. Furthermore, the possible degradation pathways of ONZ degradation were proposed according to the variation of ions in the system. Overall, the study demonstrated that the nZVI/BC system has potential for removing ONZ from wastewater.

Supplementary Materials: The following are available online at http://www.mdpi.com/1660-4601/17/4/1324/s1: Table S1. The Fe/C mass ratio and pHPZC of nZVI, BC and different nZVI-BC composites; Figure S1. The removal efficiency of ONZ and $\mathrm{pH}$ change during the degradation of ONZ. Operating conditions: $\mathrm{C}_{0}=100 \mathrm{mg} / \mathrm{L}, \mathrm{pH}=3.0$, $\mathrm{T}=25^{\circ} \mathrm{C},\left[\mathrm{H}_{2} \mathrm{O}_{2}\right]_{0}=12 \mathrm{mM}, \mathrm{nZVI}-\mathrm{BC}_{3}=0.3 \mathrm{~g} / \mathrm{L}$; Figure S2. The removal efficiency of COD and TOC in different systems. Operating conditions: $\mathrm{C}_{0}=100 \mathrm{mg} / \mathrm{L}, \mathrm{pH}=3.0, \mathrm{~T}=25^{\circ} \mathrm{C}$, (1) nZVI-BC system: $\mathrm{nZVI}-\mathrm{BC} \mathrm{C}_{3}=0.3 \mathrm{~g} / \mathrm{L}$; (2) nZVI-BC/H2O2 system: nZVI-BC $3=0.3 \mathrm{~g} / \mathrm{L},\left[\mathrm{H}_{2} \mathrm{O}_{2}\right]_{0}=12 \mathrm{mM}$; Figure S3. Plots of pseudo-first-order (a) and pseudo-second-order models (b). Operating conditions: $\mathrm{C}_{0}=100 \mathrm{mg} / \mathrm{L}, \mathrm{pH}=3.0,\left[\mathrm{H}_{2} \mathrm{O}_{2}\right]_{0}=12 \mathrm{mM}, \mathrm{nZVI}-\mathrm{BC}_{3}=$ $0.3 \mathrm{~g} / \mathrm{L}$; Figure S4: The concentration of different ions. Operating conditions: $\mathrm{C}_{0}=100 \mathrm{mg} / \mathrm{L}, \mathrm{pH}=3.0, \mathrm{~T}=25^{\circ} \mathrm{C}$, $\left[\mathrm{H}_{2} \mathrm{O}_{2}\right]_{0}=12 \mathrm{mM}, \mathrm{nZVI}-\mathrm{BC}_{3}=0.3 \mathrm{~g} / \mathrm{L}$.

Author Contributions: Conceptualization, Y.Z.; methodology, Y.Z.; software, Y.Z.; validation, Y.Z.; formal analysis, Y.Z.; investigation, Y.Z.; resources, L.Z.; data curation, Y.Z.; writing-original draft preparation, Y.Z.; writing-review and editing, Y.Y. and P.S.; visualization, Y.Z.; supervision, L.Z.; project administration, L.Z.; funding acquisition, L.Z. All authors have read and agreed to the published version of the manuscript.

Funding: This work was sponsored by the National Natural Science Foundation of China (21276182).

Acknowledgments: The authors gratefully acknowledge the National Science Foundation Project of China.

Conflicts of Interest: The authors declare no conflict of interest. The funders had no role in the design of the study; in the collection, analyses, or interpretation of data; in the writing of the manuscript, or in the decision to publish the results.

\section{References}

1. Lamp, K.C.; Freeman, C.D.; Klutman, N.E.; Lacy, M.K. Pharmacokinetics and Pharmacodynamics of the Nitroimidazole Antimicrobials. Clin. Pharmacokinet. 1999, 36, 353-373. [CrossRef] [PubMed] 
2. Jokipii, A.M.M.; Jokipii, L. Metronidazole, tinidazole, ornidazole and anaerobic infections of the middle ear, maxillary sinus and central nervous system. Scand. J. Infect. Dis. Supplementum 1981, 26, 123-129.

3. López Nigro, M.M.; Palermo, A.M.; Mudry, M.D.; Carballo, M.A. Cytogenetic evaluation of two nitroimidazole derivatives. Toxicol. Vitr. 2003, 17, 35-40. [CrossRef]

4. Rodriguez Ferreiro, G.; Cancino Badías, L.; Lopez-Nigro, M.; Palermo, A.; Mudry, M.; González Elio, P.; Carballo, M.A. DNA single strand breaks in peripheral blood lymphocytes induced by three nitroimidazole derivatives. Toxicol. Lett. 2002, 132, 109-115. [CrossRef]

5. Trinh, S.; Reysset, G. Mutagenic action of 5-nitroimidazoles: In vivo induction of GC $\rightarrow$ CG transversion in two Bacteroides fragilis reporter genes. Mutat. Res. 1998, 398, 55-65. [CrossRef]

6. Tuc Dinh, Q.; Alliot, F.; Moreau-Guigon, E.; Eurin, J.; Chevreuil, M.; Labadie, P. Measurement of trace levels of antibiotics in river water using on-line enrichment and triple-quadrupole LC-MS/MS. Talanta 2011, 85, 1238-1245. [CrossRef]

7. Zhao, J.; Yao, B.; He, Q.; Zhang, T. Preparation and properties of visible light responsive Y3+ doped Bi5Nb3O15 photocatalysts for Ornidazole decomposition. J. Hazard. Mater. 2012, 229-230, 151-158. [CrossRef]

8. Puttaswamy; Sukhdev, A.; Shubha, J.P. Kinetics and reactivities of ruthenium(III)- and osmium(VIII)-catalyzed oxidation of ornidazole with chloramine-T in acid and alkaline media: A mechanistic approach. J. Mol. Catal. A Chem. 2009, 310, 24-33. [CrossRef]

9. Zazo, J.A.; Casas, J.A.; Mohedano, A.F.; Gilarranz, M.A.; Rodríguez, J.J. Chemical Pathway and Kinetics of Phenol Oxidation by Fenton's Reagent. Environ. Sci. Technol. 2005, 39, 9295-9302. [CrossRef]

10. Hsueh, C.L.; Huang, Y.H.; Wang, C.C.; Chen, C.Y. Degradation of azo dyes using low iron concentration of Fenton and Fenton-like system. Chemosphere 2005, 58, 1409-1414. [CrossRef]

11. Luo, M.; Bowden, D.; Brimblecombe, P. Catalytic property of Fe-Al pillared clay for Fenton oxidation of phenol by $\mathrm{H}_{2} \mathrm{O}_{2}$. Appl. Catal. B Environ. 2009, 85, 201-206. [CrossRef]

12. Segura, Y.; Martínez, F.; Melero, J.A. Effective pharmaceutical wastewater degradation by Fenton oxidation with zero-valent iron. Appl. Catal. B Environ. 2013, 136-137, 64-69. [CrossRef]

13. Zha, S.; Cheng, Y.; Gao, Y.; Chen, Z.; Megharaj, M.; Naidu, R. Nanoscale zero-valent iron as a catalyst for heterogeneous Fenton oxidation of amoxicillin. Chem. Eng. J. 2014, 255, 141-148. [CrossRef]

14. Wang, L.; Yang, J.; Li, Y.; Lv, J.; Zou, J. Removal of chlorpheniramine in a nanoscale zero-valent iron induced heterogeneous Fenton system: Influencing factors and degradation intermediates. Chem. Eng. J. 2016, 284, 1058-1067. [CrossRef]

15. Cai, J.; Ma, H.; Zhang, J.; Song, Q.; Du, Z.; Huang, Y.; Xu, J. Gold Nanoclusters Confined in a Supercage of Y Zeolite for Aerobic Oxidation of HMF under Mild Conditions. Chem. A Eur. J. 2013, 19, 14215-14223. [CrossRef]

16. Gonzalez-Olmos, R.; Martin, M.J.; Georgi, A.; Kopinke, F.-D.; Oller, I.; Malato, S. Fe-zeolites as heterogeneous catalysts in solar Fenton-like reactions at neutral pH. Appl. Catal. B Environ. 2012, 125, 51-58. [CrossRef]

17. Wang, Y.; Zhao, H.; Zhao, G. Iron-copper bimetallic nanoparticles embedded within ordered mesoporous carbon as effective and stable heterogeneous Fenton catalyst for the degradation of organic contaminants. Appl. Catal. B Environ. 2015, 164, 396-406. [CrossRef]

18. Yang, S.; Wu, P.; Yang, Q.; Zhu, N.; Lu, G.; Dang, Z. Regeneration of iron-montmorillonite adsorbent as an efficient heterogeneous Fenton catalytic for degradation of Bisphenol A: Structure, performance and mechanism. Chem. Eng. J. 2017, 328, 737-747. [CrossRef]

19. Wang, J.; Yao, Z.; Wang, Y.; Xia, Q.; Chu, H.; Jiang, Z. Preparation of immobilized coating Fenton-like catalyst for high efficient degradation of phenol. Environ. Pollut. 2017, 224, 552-558. [CrossRef]

20. Ahmad, M.; Lee, S.S.; Dou, X.; Mohan, D.; Sung, J.-K.; Yang, J.E.; Ok, Y.S. Effects of pyrolysis temperature on soybean stover- and peanut shell-derived biochar properties and TCE adsorption in water. Bioresour. Technol. 2012, 118, 536-544. [CrossRef]

21. Liu, W.J.; Jiang, H.; Yu, H.Q. Development of Biochar-Based Functional Materials: Toward a Sustainable Platform Carbon Material. Chem. Rev. 2015, 115, 12251-12285. [CrossRef] [PubMed]

22. Yan, J.; Han, L.; Gao, W.; Xue, S.; Chen, M. Biochar supported nanoscale zerovalent iron composite used as persulfate activator for removing trichloroethylene. Bioresour. Technol. 2015, 175, 269-274. [CrossRef] [PubMed] 
23. Hussain, I.; Li, M.; Zhang, Y.; Li, Y.; Huang, S.; Du, X.; Liu, G.; Hayat, W.; Anwar, N. Insights into the mechanism of persulfate activation with $\mathrm{nZVI} / \mathrm{BC}$ nanocomposite for the degradation of nonylphenol. Chem. Eng. J. 2017, 311, 163-172. [CrossRef]

24. Zhang, W.; Gao, H.; He, J.; Yang, P.; Wang, D.; Ma, T.; Xia, H.; Xu, X. Removal of norfloxacin using coupled synthesized nanoscale zero-valent iron (nZVI) with $\mathrm{H}_{2} \mathrm{O}_{2}$ system: Optimization of operating conditions and degradation pathway. Sep. Purif. Technol. 2017, 172, 158-167. [CrossRef]

25. Chen, J.; Zhu, J.; Da, Z.; Xu, H.; Yan, J.; Ji, H.; Shu, H.; Li, H. Improving the photocatalytic activity and stability of graphene-like BN/AgBr composites. Appl. Surf. Sci. 2014, 313, 1-9. [CrossRef]

26. Hu, M.; Hui, K.S.; Hui, K.N. Role of graphene in $\mathrm{MnO}_{2}$ /graphene composite for catalytic ozonation of gaseous toluene. Chem. Eng. J. 2014, 254, 237-244. [CrossRef]

27. Xia, S.; Gu, Z.; Zhang, Z.; Zhang, J.; Hermanowicz, S.W. Removal of chloramphenicol from aqueous solution by nanoscale zero-valent iron particles. Chem. Eng. J. 2014, 257, 98-104. [CrossRef]

28. Lyu, H.; Tang, J.; Huang, Y.; Gai, L.; Zeng, E.Y.; Liber, K.; Gong, Y. Removal of hexavalent chromium from aqueous solutions by a novel biochar supported nanoscale iron sulfide composite. Chem. Eng. J. 2017, 322, 516-524. [CrossRef]

29. Qian, L.; Zhang, W.; Yan, J.; Han, L.; Chen, Y.; Ouyang, D.; Chen, M. Nanoscale zero-valent iron supported by biochars produced at different temperatures: Synthesis mechanism and effect on $\mathrm{Cr}(\mathrm{VI})$ removal. Environ. Pollut. 2017, 223, 153-160. [CrossRef]

30. Yen, M.Y.; Teng, C.C.; Hsiao, M.C.; Liu, P.I.; Chuang, W.P.; Ma, C.-C.M.; Hsieh, C.K.; Tsai, M.C.; Tsai, C.H. Platinum nanoparticles/graphene composite catalyst as a novel composite counter electrode for high performance dye-sensitized solar cells. J. Mater. Chem. 2011, 21, 12880-12888. [CrossRef]

31. Fang, Z.; Chen, J.; Qiu, X.; Qiu, X.; Cheng, W.; Zhu, L. Effective removal of antibiotic metronidazole from water by nanoscale zero-valent iron particles. Desalination 2011, 268, 60-67. [CrossRef]

32. Li, P.; Lin, K.; Fang, Z.; Wang, K. Enhanced nitrate removal by novel bimetallic Fe/Ni nanoparticles supported on biochar. J. Clean. Prod. 2017, 151, 21-33. [CrossRef]

33. Wu, J.; Yi, Y.; Li, Y.; Fang, Z.; Tsang, E.P. Excellently reactive Ni/Fe bimetallic catalyst supported by biochar for the remediation of decabromodiphenyl contaminated soil: Reactivity, mechanism, pathways and reducing secondary risks. J. Hazard. Mater. 2016, 320, 341-349. [CrossRef] [PubMed]

34. Liu, A.; Liu, J.; Zhang, W.X. Transformation and composition evolution of nanoscale zero valent iron (nZVI) synthesized by borohydride reduction in static water. Chemosphere 2015, 119, 1068-1074. [CrossRef] [PubMed]

35. Kuang, Y.; Wang, Q.; Chen, Z.; Megharaj, M.; Naidu, R. Heterogeneous Fenton-like oxidation of monochlorobenzene using green synthesis of iron nanoparticles. J. Colloid Interface Sci. 2013, 410, 67-73. [CrossRef] [PubMed]

36. Su, H.; Fang, Z.; Tsang, P.E.; Fang, J.; Zhao, D. Stabilisation of nanoscale zero-valent iron with biochar for enhanced transport and in-situ remediation of hexavalent chromium in soil. Environ. Pollut. 2016, 214, 94-100. [CrossRef]

37. Lian, L.; Yao, B.; Hou, S.; Fang, J.; Yan, S.; Song, W. Kinetic Study of Hydroxyl and Sulfate Radical-Mediated Oxidation of Pharmaceuticals in Wastewater Effluents. Environ. Sci. Technol. 2017, 51, 2954-2962. [CrossRef]

38. Tian, X.; Jin, H.; Nie, Y.; Zhou, Z.; Yang, C.; Li, Y.; Wang, Y. Heterogeneous Fenton-like degradation of ofloxacin over a wide $\mathrm{pH}$ range of 3.6-10.0 over modified mesoporous iron oxide. Chem. Eng. J. 2017, 328, 397-405. [CrossRef]

39. Zhang, Y.; Zhao, L.; Yang, Y.; Sun, P. Degradation of the antibiotic ornidazole in aqueous solution by using nanoscale zero-valent iron particles: Kinetics, mechanism, and degradation pathway. RSC Adv. 2018, 8, 35062-35072. [CrossRef]

40. Hoffer, M.; Grunberg, E. Synthesis and antiprotozoal activity of 1-(3-chloro-2-hydroxypropyl)-substituted nitroimidazoles. J. Med. Chem. 1974, 17, 1019-1020. [CrossRef]

41. Babuponnusami, A.; Muthukumar, K. Removal of phenol by heterogenous photo electro Fenton-like process using nano-zero valent iron. Sep. Purif. Technol. 2012, 98, 130-135. [CrossRef]

42. Ramirez, J.H.; Costa, C.A.; Madeira, L.M.; Mata, G.; Vicente, M.A.; Rojas-Cervantes, M.L.; López-Peinado, A.J.; Martín-Aranda, R.M. Fenton-like oxidation of Orange II solutions using heterogeneous catalysts based on saponite clay. Appl. Catal. B Environ. 2007, 71, 44-56. [CrossRef] 
43. Rusevova, K.; Kopinke, F.-D.; Georgi, A. Nano-sized magnetic iron oxides as catalysts for heterogeneous Fenton-like reactions-Influence of $\mathrm{Fe}(\mathrm{II}) / \mathrm{Fe}(\mathrm{III})$ ratio on catalytic performance. J. Hazard. Mater. 2012, 241-242, 433-440. [CrossRef] [PubMed]

44. Babuponnusami, A.; Muthukumar, K. Advanced oxidation of phenol: A comparison between Fenton, electro-Fenton, sono-electro-Fenton and photo-electro-Fenton processes. Chem. Eng. J. 2012, 183, 1-9. [CrossRef]

45. Xu, L.; Wang, J. A heterogeneous Fenton-like system with nanoparticulate zero-valent iron for removal of 4-chloro-3-methyl phenol. J. Hazard. Mater. 2011, 186, 256-264. [CrossRef]

46. Herney-Ramirez, J.; Vicente, M.A.; Madeira, L.M. Heterogeneous photo-Fenton oxidation with pillared clay-based catalysts for wastewater treatment: A review. Appl. Catal. B Environ. 2010, 98, 10-26. [CrossRef]

47. Wiegand, H.L.; Orths, C.T.; Kerpen, K.; Lutze, H.V.; Schmidt, T.C. Investigation of the Iron-Peroxo Complex in the Fenton Reaction: Kinetic Indication, Decay Kinetics, and Hydroxyl Radical Yields. Environ. Sci. Technol. 2017, 51, 14321-14329. [CrossRef]

48. Chu, L.; Wang, J.; Dong, J.; Liu, H.; Sun, X. Treatment of coking wastewater by an advanced Fenton oxidation process using iron powder and hydrogen peroxide. Chemosphere 2012, 86, 409-414. [CrossRef]

49. Xia, Q.; Jiang, Z.; Wang, J.; Yao, Z. A facile preparation of hierarchical dendritic zero-valent iron for Fenton-like degradation of phenol. Catal. Commun. 2017, 100, 57-61. [CrossRef]

50. Mitsika, E.E.; Christophoridis, C.; Fytianos, K. Fenton and Fenton-like oxidation of pesticide acetamiprid in water samples: Kinetic study of the degradation and optimization using response surface methodology. Chemosphere 2013, 93, 1818-1825. [CrossRef]

51. Hong, J.; Lu, S.; Zhang, C.; Qi, S.; Wang, Y. Removal of Rhodamine B under visible irradiation in the presence of $\mathrm{Fe} 0, \mathrm{H}_{2} \mathrm{O}_{2}$, citrate and aeration at circumneutral $\mathrm{pH}$. Chemosphere 2011, 84, 1542-1547. [CrossRef] [PubMed]

52. Wu, Y.; Zeng, S.; Wang, F.; Megharaj, M.; Naidu, R.; Chen, Z. Heterogeneous Fenton-like oxidation of malachite green by iron-based nanoparticles synthesized by tea extract as a catalyst. Sep. Purif. Technol. 2015, 154, 161-167. [CrossRef]

53. Wang, X.; Wang, A.; Lu, M.; Ma, J. Synthesis of magnetically recoverable Fe0/graphene- $\mathrm{TiO}_{2}$ nanowires composite for both reduction and photocatalytic oxidation of metronidazole. Chem. Eng. J. 2018, 337, 372-384. [CrossRef]

54. Xu, X.R.; Li, X.Z. Degradation of azo dye Orange $\mathrm{G}$ in aqueous solutions by persulfate with ferrous ion. Sep. Purif. Technol. 2010, 72, 105-111. [CrossRef]

55. Ding, Y.; Huang, W.; Ding, Z.; Nie, G.; Tang, H. Dramatically enhanced Fenton oxidation of carbamazepine with easily recyclable microscaled $\mathrm{CuFeO}_{2}$ by hydroxylamine: Kinetic and mechanism study. Sep. Purif. Technol. 2016, 168, 223-231. [CrossRef]

56. Forouzesh, M.; Ebadi, A.; Aghaeinejad-Meybodi, A. Degradation of metronidazole antibiotic in aqueous medium using activated carbon as a persulfate activator. Sep. Purif. Technol. 2019, 210, 145-151. [CrossRef]

57. Santana, D.R.; Espino-Estévez, M.R.; Santiago, D.E.; Méndez, J.A.O.; González-Díaz, O.; Doña-Rodríguez, J.M. Treatment of aquaculture wastewater contaminated with metronidazole by advanced oxidation techniques. Environ. Nanotechnol. Monit. Manag. 2017, 8, 11-24. [CrossRef]

(C) 2020 by the authors. Licensee MDPI, Basel, Switzerland. This article is an open access article distributed under the terms and conditions of the Creative Commons Attribution (CC BY) license (http://creativecommons.org/licenses/by/4.0/). 